\title{
IMPLEMENTATION OF THE TPACK FRAMEWORK TO MEASURE INTEGRATION OF TECHNOLOGY, PEDAGOGY AND THE CONTENT OF LECTURERS IN MATHEMATICS EDUCATION
}

\author{
Hepsi Nindiasari ${ }^{1}$, Nena Restiana ${ }^{2}$, Aan Subhan Pamungkas ${ }^{3}$ \\ 1,2,3 Universitas Sultan Ageng Tirtayasa, Jl Raya Jakarta Km 4 Pakupatan Serang, Indonesia \\ email: hepsinindiasari@untirta.ac.id
}

\begin{abstract}
One of the obstacles using technology is the lack of teacher understanding of technology, therefore this study aims to determine the understanding of lecturers of mathematics education on the integration of technology in learning using the TPACK (Technological, Pedagogical, Content Knowledge) framework, a few of research that applying TPACK in universities. Furthermore, the both effect of gender and age of teaching on TPACK were analyzed on TPACK using analysis of variance (ANOVA). The results of this study are Power point applications are technologies that are widely used by mathematics education lecturers by $40.9 \%$. PCK, PK and CK components have a strong positive effect on TPACK perceptions of mathematics education lecturers. The average value of TPACK components is TK 3.95; CK 4.01; PK 4.08; 4.02 PCK; TCK 4.04; TPK 4.02; TPACK 3.96. For an in-depth analysis of gender and age of teaching factors on the TPACK component. This study found that gender and duration of teaching was no significant influence between the understanding of mathematics education lecturers and the seven components of TPACK.
\end{abstract}

Keywords: mathematics, lecturer, technologie, content, knowledge

\begin{abstract}
Abstrak
Salah satu kendala dalam penggunaan teknologi pembelajaran adalah pada kurangnya pemahaman pengajar terhadap teknologi, oleh karena itu penelitian ini bertujuan untuk mengetahui pemahaman dosen pendidikan matematika terhadap integrasi teknologi pada pembelajaran dengan menggunakan kerangka TPACK (Technological, Pedagogical, Content Knowledge), dimana masih sedikit literatur yang mengkaji TPACK pada perguruan tinggi. Selanjutnya, jenis kelamin dan lama mengajar dianalisis pengaruhnya terhadap TPACK dengan menggunakan analysis of variance (ANOVA). Hasil penelitian ini adalah Aplikasi power point merupakan teknologi yang banyak digunakan oleh dosen pendidikan matematika sebesar 40,9\%, komponen PCK, PK dan CK berpengaruh positif kuat terhadap persepsi TPACK dosen pendidikan matematika. Nilai rata-rata komponen TPACK adalah TK 3,95; CK 4,01; PK 4,08; PCK 4,02; TCK 4,04; TPK 4,02; TPACK 3,96. Untuk analisis mendalam terhadap faktor jenis kelamin dan lama mengajar terhadap komponen TPACK didapatkan bahwa, faktor jenis kelamin dan lama mengajar tidak ada pengaruh signifikan antara pemahaman dosen pendidikan matematika terhadap ketujuh komponen.
\end{abstract}

Kata kunci: matematika, dosen, teknologi, konten, pengetahuan

\section{INTRODUCTION}

The emergence of Information and Communication Technology (ICT) has an impact on several things, including the field of education. Mathematics education is also required to make changes according to the development of ICT (Haapasalo, 2017). This change is marked by the use of technology in the learning process such as learning media.

The use of this technology is expected to increase the effectiveness of learning. Eng (2005) explains that the use of ICT can have a positive effect on student learning. Keong, 
Horani, \& Daniel (2005) state that learning mathematics using ICT can make learning more effective and provide increased student ability to understand basic concepts. Andreou (2017) adds that the use of technology makes students increase in problem-solving abilities, critical thinking, and comprehensive understanding of mathematical concepts.

One of the determining factors for the successful use of technology in learning is the understanding of technology teachers or users (Englund, Olofsson, \& Price, 2017). Teachers must have expertise in the use of technology to support learning and improve student understanding (Otero et al., 2005). However, there are still obstacles to the understanding of teachers in using this technology, including the limited understanding and mastery of technology and teachers' perceptions of innovative learning techniques (Andreou, 2017).

The existence of these obstacles encourages various studies to evaluate teacher understanding in integrating ICT. The evaluation method used can use the Technological, Pedagogical, Content, Knowledge (TPACK) framework. Koehler and Mishra (2009) explain that TPACK is the basis for integration between the components of content knowledge (CK), pedagogical knowledge (PK), and technological knowledge (TK) as seen in Figure 1. In general, CK is described as the teaching ability of the material invited. PK is the teacher's ability to know how to teach appropriately. Meanwhile, TK is the ability of a teacher to use various kinds of technology sources in learning.

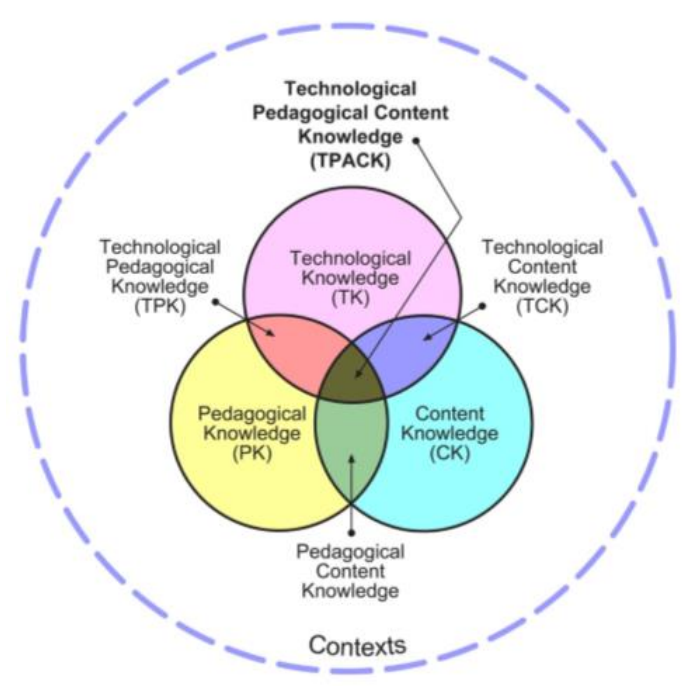

Figure 1. TPACK Framework

In addition to the three main components, there are areas of intersection between these components, namely PCK (pedagogical content knowledge), TPK (technological 
pedagogical knowledge), and TCK (technological content knowledge), while TPACK (technological pedagogical content knowledge) is the middle point. Chai, Koh, \& Tsai (2011) state that these 7 components have a positive and significant relationship.

Research using the TPACK framework has been carried out in several ways. One of them is TPACK which is used to explore the use of ICT in mathematics learning (Chai, Koh, Tsai, \& Tan, 2011; Jang \& Tsai, 2012; Liang \& Luo, 2016). Research on understanding of TPACK is associated with gender and length of teaching where gender and length of teaching have a relationship with several components of TPACK. According to Lin, Tsai, Chai, \& Lee (2013) the gender factor is related to TK, TPK, TCK and TPC, while different results were obtained by Liu, Zhang, \& Wang (2015) where gender is related to PK and TCK. TPACK is also associated with the length of teaching, where Chuang \& Ho (2011) stated that the length of teaching has a relationship with PK, CK, and PCK, while Liu, Zhang, \& Wang (2015) stated that the length of teaching is related to almost all TPACK components except PCK .

Various literature studies related to TPACK focus on teacher understanding at the school level (Jang \& Tsai, 2012; Zelkowski, Gleason, \& Cox, 2013; Sang, Tondeur, Chai, \& Dong, 2016; Restiana, 2018), but there is still little literature that discusses TPACK in college. One of the studies that explains TPACK in higher education is Benson \& Ward (2013).

Benson \& Ward (2013) conclude that every professor has a different understanding of the use of technology and a professor whose understanding is good in pedagogical knowledge will tend to show TPACK integration. However, this research is still qualitative in nature and limited to individuals without involving the influence of gender and length of teaching.

Thus, research on the mastery of TPACK in college teachers and its relationship with gender and length of teaching still needs to be done, so this research is carried out in order to fill this gap.

\section{METHODS}

This research is a quantitative correlational study which aims to determine the understanding of mathematics education lecturers in the use of learning technology with the TPACK framework approach and to see the relationship between gender and length of teaching on the TPACK ability of the lecturer. This research was conducted in January-March 2019, with the research subjects being 22 mathematics education lecturers in Banten. 
The research procedure consists of three stages, namely the stage of preparation, data collection and processing, and data analysis. In the research preparation stage, preparing a research instrument in the form of a TPACK questionnaire which is a modification of Zelkowski, Gleason, Cox, \& Bismarck (2013) with adjustments to advanced mathematical material or content. Then the research subjects were taken by 22 mathematics education lecturers using the sample method. Collecting data using the TPACK questionnaire which consists of 42 question items.

While the TPACK questionnaire data analysis was carried out first using Exploratory Factor Analysis, namely Principal Component Analysis (PCA). This analysis tries to find the relationship between a number of variables that are independent of each other so that one or several sets of variables that are fewer than the initial variables can be created. The variables that have the greatest correlation will be clustered to form a set of variables.

\section{RESULTS AND DISCUSSION}

The technology used by lecturers in the field of mathematics education in Banten, mostly uses power point applications (40.9\%), some others use collaboration between whiteboards, power point applications and interactive computer applications in the teaching process $(27.3 \%)$. using whiteboard technology as a learning medium (18.2\%) followed by collaboration between power point applications and interactive computer applications $(9.1 \%)$ and using interactive computer applications (4.5\%).

For the validity results proven by using factor analysis, it can be seen in Table 2 . The main varimax-rotated matrix analysis was carried out to identify whether the items in the scale could be grouped with independent and significant factors. A principal component analysis is concerned with how certain variables will contribute to components as well as with the formation of existing components in the data (Field, 2009). While the lower limit of loading the accepted item factor becomes 0.40 (Field, 2009)

This process shows that items TK2, TK, TK5, CK5, PK1, PK3, TPK1, TPK2 and TPACK1 are not related to 7 factors, while other items are related to 7 existing factors. The results of the validity of each item by looking at the results of the correlation value for the items were obtained between $r=0.018$ (TK3) to $r=0.929($ TK4). 
Table 1. Rotated Component Matrix

\begin{tabular}{|c|c|c|c|c|c|c|c|c|}
\hline \multirow[t]{2}{*}{ Item } & \multicolumn{7}{|c|}{ Components of TPACK } & \multirow{2}{*}{$\begin{array}{c}\text { Corrected Item-Total } \\
\text { Correlation }\end{array}$} \\
\hline & TK & CK & PK & PCK & TCK & TPK & TPACK & \\
\hline TK1 & 0,869 & & & & & & & 0,347 \\
\hline TK2 & 0,205 & & & & & & & $-0,136$ \\
\hline TK3 & 0,018 & & & & & & & $-0,505$ \\
\hline TK4 & 0,929 & & & & & & & 0,196 \\
\hline TK5 & 0,473 & & & & & & & 0,565 \\
\hline TK6 & 0,791 & & & & & & & 0,510 \\
\hline TK7 & 0,842 & & & & & & & 0,371 \\
\hline CK8 & & 0,856 & & & & & & 0,524 \\
\hline СК9 & & 0,639 & & & & & & 0,433 \\
\hline CK10 & & 0,800 & & & & & & 0,319 \\
\hline CK11 & & 0,715 & & & & & & 0,449 \\
\hline CK12 & & 0,484 & & & & & & 0,388 \\
\hline PK13 & & & 0,391 & & & & & 0,585 \\
\hline PK14 & & & 0,551 & & & & & 0,527 \\
\hline PK15 & & & 0,498 & & & & & 0,433 \\
\hline PK16 & & & 0,722 & & & & & 0,455 \\
\hline PK17 & & & 0,691 & & & & & 0,560 \\
\hline PK18 & & & 0,687 & & & & & 0,505 \\
\hline PK19 & & & 0,888 & & & & & 0,484 \\
\hline PK20 & & & 0,825 & & & & & 0,591 \\
\hline PCK21 & & & & 0,679 & & & & 0,689 \\
\hline PCK22 & & & & 0,890 & & & & 0,673 \\
\hline TCK23 & & & & & 0,631 & & & 0,526 \\
\hline TCK24 & & & & & 0,869 & & & 0,374 \\
\hline TPK25 & & & & & & 0,312 & & 0,462 \\
\hline TPK26 & & & & & & 0,442 & & 0,282 \\
\hline TPK27 & & & & & & 0,801 & & 0,350 \\
\hline TPK28 & & & & & & 0,871 & & 0,185 \\
\hline TPK29 & & & & & & 0,759 & & 0,449 \\
\hline TPK30 & & & & & & 0,829 & & 0,673 \\
\hline TPK31 & & & & & & 0,630 & & 0,634 \\
\hline TPK32 & & & & & & 0,544 & & 0,697 \\
\hline TPK33 & & & & & & 0,762 & & 0,341 \\
\hline TPK34 & & & & & & 0,867 & & 0,358 \\
\hline TPK35 & & & & & & 0,831 & & 0,213 \\
\hline TPACK36 & & & & & & & 0,448 & 0,549 \\
\hline TPACK37 & & & & & & & 0,558 & 0,551 \\
\hline TPACK38 & & & & & & & 0,879 & 0,627 \\
\hline TPACK39 & & & & & & & 0,771 & 0,458 \\
\hline TPACK40 & & & & & & & 0,753 & 0,444 \\
\hline TPACK41 & & & & & & & 0,869 & 0,336 \\
\hline TPACK42 & & & & & & & 0,726 & 0,532 \\
\hline
\end{tabular}

The results of the correlation between TPACK components showed that there was a strong positive correlation between PCK-TPACK $(r=0.768)$, TCK-TPK $(r=0.680)$, CK-PK $(r=$ 0.626), CK-PCK $(r=0.612)$, CK-TPACK $(r=0.605)$, PK-PCK $(r=0.577)$, PK-TPACK $(r=0.553)$ 
according to Table 4 the correlation between TPACK components. For components with moderate positive correlation were PK-TPK $(r=0.485)$, TK-PCK $(r=0.456)$, PCK-TPK $(r=0.455)$, TK-TCK $(r=0.426)$, TPK-TPACK $(r=0.443))$. Meanwhile, the others have a weak correlation. Thus, PCK, CK and PK are components that have a significant effect on the perception of TPACK in mathematics education lecturers, this result means that mathematics education lecturers are oriented towards pedagogical aspects, content knowledge, while technological aspects have not become a concern, but only become supporting factors such as using in learning media this can be seen from the moderate correlation between TPK and TPACK.

Table 2. Correlation Between TPACK Components

\begin{tabular}{|c|c|c|c|c|c|c|c|c|}
\hline & & TK & CK & PK & PCK & TCK & TPK & TPACK \\
\hline \multirow{3}{*}{ TK } & Pearson Correlation & 1 & 0,090 & 0,167 & $0,456^{*}$ & $0,426^{*}$ & 0,278 & 0,239 \\
\hline & Sig. (2-tailed) & & 0,690 & 0,457 & 0,033 & 0,048 & 0,210 & 0,284 \\
\hline & $\mathrm{N}$ & & 22 & 22 & 22 & 22 & 22 & 22 \\
\hline \multirow{3}{*}{ CK } & Pearson Correlation & & 1 & $0,626^{* *}$ & $0,612^{* *}$ & 0,106 & 0,265 & $0,605^{* *}$ \\
\hline & Sig. (2-tailed) & & & 0,002 & 0,002 & 0,639 & 0,233 & 0,003 \\
\hline & $\mathrm{N}$ & & & 22 & 22 & 22 & 22 & 22 \\
\hline \multirow{3}{*}{ PK } & Pearson Correlation & & & 1 & $0,577^{* *}$ & 0,281 & $0,485^{*}$ & $0,553^{* *}$ \\
\hline & Sig. (2-tailed) & & & & 0,005 & 0,205 & 0,022 & 0,008 \\
\hline & $\mathrm{N}$ & & & & 22 & 22 & 22 & 22 \\
\hline \multirow{3}{*}{ PCK } & Pearson Correlation & & & & 1 & 0,282 & $0,455^{*}$ & $0,768^{* *}$ \\
\hline & Sig. (2-tailed) & & & & & 0,203 & 0,033 & 0,000 \\
\hline & $\mathrm{N}$ & & & & & 22 & 22 & 22 \\
\hline \multirow{3}{*}{ TCK } & Pearson Correlation & & & & & 1 & $0,680^{* *}$ & 0,252 \\
\hline & Sig. (2-tailed) & & & & & & 0,001 & 0,257 \\
\hline & $\mathrm{N}$ & & & & & & 22 & 22 \\
\hline \multirow{3}{*}{ TPK } & Pearson Correlation & & & & & & 1 & $0,443^{*}$ \\
\hline & Sig. (2-tailed) & & & & & & & 0,039 \\
\hline & $\mathrm{N}$ & & & & & & & 22 \\
\hline
\end{tabular}

Table 3. Independent Sampel t-test

\begin{tabular}{cccccccc}
\hline & TK & CK & PK & PCK & TCK & TPK & TPACK \\
\hline Gender & $-0,696$ & $-1,368$ & $-0,935$ & $-0,393$ & 0,519 & 0,277 & $-1,569$ \\
Length of Teaching & $-0,860$ & $-1,322$ & $-0,605$ & $-1,963$ & $-0,693$ & $-1,594$ & $-1,959$ \\
\hline
\end{tabular}

Based on the average value of each TPACK component, the highest value was PK (4.08) followed by TCK (4.04), PCK (4.02), TPK (4.02), CK (4.01), TPACK (3.96) and TK (3.95). From these results indicate that mathematics education lecturers at the City of Serang University 
have scores that are above average (good), but there is still a need to make improvements to the lecturers' understanding of the use of the latest technology.

While the analysis of the effect of gender (JK) and length of teaching (LM) on TPACK perceptions using ANOVA at a significance level of $5 \%$ and $\mathrm{df}=22-1$ obtained t table $=1.721$, and tcount as in table 4. Mathematics education lecturers' perceptions of TPACK in terms of gender and length of teaching. Thus, it can be concluded that the gender factor has no effect on TPACK perceptions, this is according to several previous studies (Jang \& Tsai, 2012; Liang, Chai, Koh, Yang, \& Tsai, 2013; Lin et al., 2013). This indicates that they do not understand the use of technology integration within the TPACK framework. The long teaching factor has no effect on TPACK perceptions, as research by Liang, Chai, Koh, Yang, \& Tsai (2013) and different from the results of research from Jang \& Tsai (2012), this can be due to a lack of understanding of the TPACK framework.

The factors of gender and length of teaching are factors that need to be carried out further studies related to their effect on the perception of TPACK in mathematics education lecturers after socialization of the understanding of TPACK. Research on other factors can also be considered such as technological competence, interaction with technology and learning methods.

\section{CONCLUSION}

The results of the research on the understanding of TPACK mathematics education lecturers in Banten found that the TPACK framework of the 7 components was validated, based on the TPACK item, PCK, PK and CK components had a strong positive effect on the perception of TPACK in mathematics education lecturers. This result means that mathematics education lecturers are oriented towards pedagogical aspects and content knowledge, while technological aspects have not become a concern, but only become a supporting factor such as using in learning media. This can be seen from the moderate correlation results between TPK and TPACK. For an in-depth analysis of the gender factor and the length of teaching on the understanding of the TPACK components, it was found that gender and length of teaching had no significant effect between the understanding of mathematics education lecturers on the seven TPACK components. 


\section{REFERENCES}

Andreou, L. (2017). The Contribution of Technology for Evolving Mathematical Skills in Higher Education. Cyprus International Journal of Management, 19(1), 1-4. Retrieved from http://www.geneva-

academy.ch/RULAC/international_judicial_decisions.php?id_state $=46$

Andy Field. (2009). Discovering Statistics Using SPSS Third Edition. SAGE Publications Ltd (Vol. 622). https://doi.org/10.1007/978-0-387-68969-2_13

Benson, S. N. K., \& Ward, C. L. (2013). Teaching with Technology: Using TPACK to Understand Teaching Expertise in Online Higher Education, 48(2), 153-172.

Chai, C.-S., Koh, J.-H. L., \& Tsai, C.-C. (2011). Exploring the factor structure of the constructs of Technological, Pedagogical, Content Knowledge (TPACK). The Asia-Pacific Education Researcher, 20(3), 595-603.

Chai, S., Koh, J. H. L., Tsai, C., \& Tan, L. L. W. (2011). Modeling primary school pre-service teachers ' Technological Pedagogical Content Knowledge ( TPACK ) for meaningful learning with information and communication technology ( ICT ). Computers \& Education, 57(1), 1184-1193. https://doi.org/10.1016/j.compedu.2011.01.007

Chuang, H.-H., \& Ho, C.-J. (2011). An investigation of early childhood teachers' technological pedagogical content knowledge (TPACK) in Taiwan. Journal of Kirsehir Education Faculty, 12(2), 99-117. Retrieved from http://www.doaj.org/doaj?func=abstract\&id=782294\&recNo=6\&toc=1\&uiLanguage=e $\mathrm{n}$

Eng, T. S. (2005). The impact of ICT on learning : A review of research. International Education Journal, 6(5), 635-650.

Englund, C., Olofsson, A. D., \& Price, L. (2017). Teaching with technology in higher education: understanding conceptual change and development in practice. Higher Education $\begin{array}{llll}\text { Research } & \text { and }\end{array}$ https://doi.org/10.1080/07294360.2016.1171300

Haapasalo, L. (2017). Adapting mathematics education to the needs of Adapting Mathematics Education to the Needs of ICT. The Electronic Journal of Mathematics and Technology, 1(1), 1-10. 
Jang, S., \& Tsai, M. (2012). Exploring the TPACK of Taiwanese elementary mathematics and science teachers with respect to use of interactive whiteboards. Computers \& Education, 59(2), 327-338. https://doi.org/10.1016/j.compedu.2012.02.003

Keong, C. C., Horani, S., \& Daniel, J. (2005). A Study on the Use of ICT in Mathematics Teaching. Malaysian Online Journal of Instructional Technology (MOJIT), 2(3), 43-51.

Koehler, M. J., \& Mishra, P. (2009). What Is Technological Pedagogical Content Knowledge? Contemporary Issues in Technology and Teacher Education, 9(1), 60-70.

Liang, J., Chai, C., Koh, J., Yang, C., \& Tsai, C. (2013). Surveying in-service preschool teachers' technological pedagogical content knowledge. Australasian Journal of Educational Technology, 29(4), 581-594. https://doi.org/http://dx.doi.org/10.14742/ajet.299

Liang, X., \& Luo, J. (2016). Micro-lesson Design: A Typical Learning Activity to Develop Preservice Mathematics Teachers' TPACK Framework. In Proceedings - 2015 International Conference of Educational Innovation Through Technology, EITT 2015 (Vol. 2, pp. 259263). https://doi.org/10.1109/EITT.2015.61

Lin, T., Tsai, C., Chai, C. S., \& Lee, M. (2013). Identifying Science Teachers ' Perceptions of Technological Pedagogical and Content Knowledge ( TPACK ). J Sci Educ Technol, 22, 325336. https://doi.org/10.1007/s10956-012-9396-6

Liu, Q., Zhang, S., \& Wang, Q. (2015). Surveying Chinese Teachers ' Technology, Pedagogy, and Content Knowledge. Journal of Educational Computing Research, O(152), 1-20. https://doi.org/10.1177/0735633115585929

Otero, V., Peressini, D., Meymaris, K. A., Ford, P., Garvin, T., Harlow, D., ... Mears, C. (2005). Integrating technology into teacher education: A critical framework for implementing reform. Journal of Teacher Education, 56(1), 8-23. https://doi.org/10.1177/0022487104272055

Restiana, N. (2018). Evaluasi Profil TPACK untuk Guru Matematika Sekolah Menengah Pertama di Banten. Jurnal Penelitian Pendidikan, 35(2), 167-178.

Sang, G., Tondeur, J., Chai, C. S., \& Dong, Y. (2016). Validation and profile of Chinese preservice teachers' technological pedagogical content knowledge scale. Asia-Pacific Journal of Teacher Education, 44(1), 49-65. https://doi.org/10.1080/1359866X.2014.960800

Zelkowski, J., Gleason, J., \& Cox, D. C. (2013). Validating a Reliable TPACK Instrument for Vol. 5, No. 2, July 2021, 30-39 
Secondary Mathematics Preservice Teachers. Journal of Research on Technology in Education Developing A, 2014), 37-41. https://doi.org/10.1080/15391523.2013.10782618

Zelkowski, J., Gleason, J., Cox, D. C., \& Bismarck, S. (2013). Developing and Validating a Reliable TPACK Instrument for Secondary Mathematics Preservice Teachers. Journal of Research on Technology in Education, 46(2), 173-206. https://doi.org/10.1080/15391523.2013.10782618 